\title{
Perceptions of small business executives on determinants of performance in the construction industry in Gauteng, South Africa
}

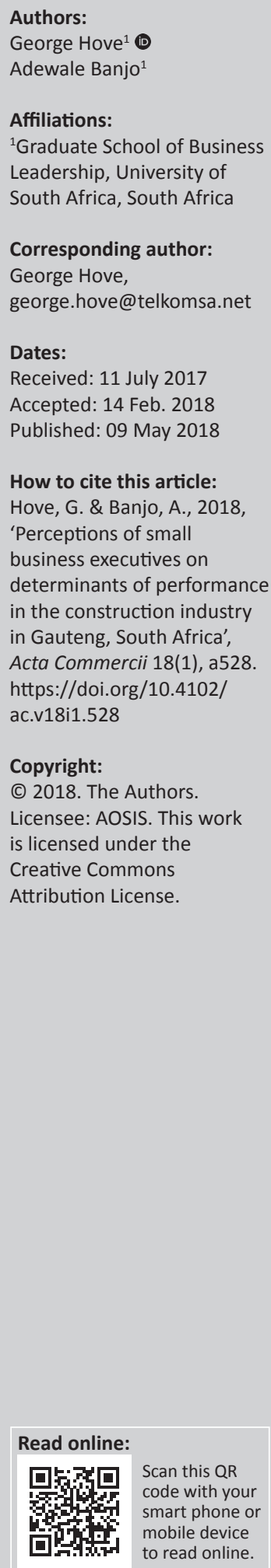

Orientation: The South African (SA) government expects emerging contractors (ECs) to become the main players in economic transformation and growth, job creation and income generation. However, ECs fail to live up to the expectations as some are characterised by low performance levels and are at risk of business closure.

Research purpose: The purpose of this research was to examine the perceptions of small business executives (SBEs) on determinants of ECs' performance so that a performance model that could guide ECs in the construction industry is developed.

Motivation for the study: Despite the significance of ECs to the SA economy, researchers have constantly omitted to identify and examine the role played by the perceptions of SBEs on the determinants of performance and this gap in the body of knowledge would be closed by this study.

Research design, approach and method: A mixed approach was used to examine the perceptions of SBEs on determinants of performance by applying both qualitative and quantitative research approaches. Data were obtained from 433 urban based ECs registered with the Construction Industry Development Board (CIDB) in the construction industry in Gauteng Province. A structured questionnaire and an interview guide were administered as the data collection instruments. Content analysis, regression analysis and multiple linear regressions were performed.

Main findings: The analysis of qualitative data demonstrated the perceptions of SBEs that financial factors, manpower, materials, machinery and equipment, project implementation, quality of work, legal and environmental factors and strategic planning were the determinants of ECs' performance. Multiple linear regressions carried out based on the perceptions of SBEs identified strategic planning, project implementation and project performance as the most statistically significant factors in predicting the performance of ECs in Gauteng Province.

Contribution and value add: Based on perceptual analysis of the ECs and multivariate results, a performance prediction model was developed. Furthermore, a new set of significant determinants of performance as perceived by SBEs in South Africa's (Gauteng Province) construction industry was established.

\section{Introduction}

The contribution of emerging contractors (ECs) to South Africa's economic development has been a focus of discourse for many years (Atkinson et al. 2012). While government policies and strategies relating to the construction industry are in favour of ECs (Greyling 2012), their performance in terms of growth and profitability has remained a concern to the policymakers (Buys \& Daluxolo 2012; Thwala \& Mvubu 2009), thus, the intended outcomes have remained elusive for ECs as the problem of weak performance persists, despite implementation of government policies to improve performance (Buys \& Daluxolo 2012; Marx 2012).

Indeed, construction industries all over the world face many challenges (Ofori 1991). However, these challenges become more complex in developing countries such as South Africa, where, for example, ECs face challenges such as lack of skills, financial instability, resource shortages and their failure to deal with key issues (Buys \& Daluxolo 2012; Rust \& Koen 2011). As a result, ECs fail to sustain their operational performances beyond the start-up phase (Herrington, Kew \& Kew 2010). 
Emerging contractors are individuals who own small businesses (at least 50\%) and are overcoming business impediments arising from the legacy of apartheid. This refers to small-scale construction enterprises in the Construction Industry Development Board (CIDB) graded 2-5. Specifically, this study has focused on ECs who can undertake contracts that are less than or equal to R1.5 million. Small business executives (SBEs) also refer to employees who make decisions for the ECs' organisational structures. These are top team members of each emerging construction organisation and include chief executive officer (CEO), chief financial officer, contract director and marketing director.

The study environment took account of the small construction industry in Gauteng Province, South Africa. The province is the economic powerhouse of the Republic of South Africa and makes the largest contribution to gross domestic product (GDP) (37.73\% compared to secondplaced, KwaZulu-Natal (KZN) at 14.9\%) (Van Wyk et al. 2011). Gauteng Province is the smallest of the nine provinces in South Africa and has a land area of $18178 \mathrm{~km}^{2}$ (Census 2011). It is landlocked and surrounded by Limpopo, Mpumalanga, North West and Free State provinces. It is divided into three metro municipalities and two district municipalities, which are further sub-divided into eight local municipalities. Although it is the smallest province, it is the most highly populated with 12.2 million people (Census 2011), which is almost $25 \%$ of the national total. It is the fastest growing province in South Africa and has experienced a population growth of over 33\% between the 1996 and 2011 censuses. As with other provinces, Gauteng Province faces challenges of high levels of unemployment and poverty and it requires job creation, provision of infrastructure, development of small businesses, education and skills development (Gauteng Online 2014).

Despite the significance of ECs to the South African (SA) economy, researchers have constantly omitted to identify and examine the role played by the perceptions of SBEs on the determinants of performance. A review of the literature has demonstrated that perceptions are critical to explain and solve problems of this nature. For example, a study by Akinsiku and Akinsulire (2012) assessed construction stakeholders' perceptions of the causes of delays and its effects on project delivery in a bid to offer solutions in minimising the occurrences of delays. Based on stakeholders' perceptions, clients' cash flow-related problems were found as the main causes of delays, while time and cost overruns were the major effects of delays in construction. However, in South Africa the perception gap has been overlooked for many years, yet if perceptions could be considered, this could be a useful means to understand the phenomenon. Therefore, the research question that arises is the following:

- What are the perceptions of SBEs on the determinants of business performance in Gauteng Province that affect sustainable growth, profitability and enhancement?

The specific objectives of this study were:
- To assess the critical incidents that have been encountered by SBEs in the construction industry and their effect on business performance.

- To assess the determinants of ECs business performance in Gauteng Province.

- To assess the perceptions of SBEs on determinants of business performance in Gauteng Province.

- To establish the relationship between the profiles of ECs and their performance in the industry.

- To characterise the perceived measures that could assist in promoting high performance amongst ECs.

\section{Theoretical foundation and literature review}

As a result of the success of Japanese companies, European and the USA companies have taken a wider view of performance measurement, with various quality and performance frameworks being introduced (Beatham et al. 2004). Although the numerous quality and performance frameworks that exist are expected to govern and improve the performance of contracting firms, ECs particularly in South Africa are still performing poorly despite these extant frameworks, including those designed for SA firms and attempts to improve ECs performance have not significantly improved ECs' performance. Some of the frameworks include the European Foundation for Quality Management (EFQM) Excellence Model in Europe, the KPI model, the Balanced Scorecard (Kaplan and Norton (1992) and the South African Construction Excellence Model (SACEM) (Dlungwana et al. 2002).

\section{Operational definition of performance}

Despite studies that have reviewed the performance construct of construction businesses (e.g. Ladzani, Smith \& Pretorius 2012; Windapo \& Oladapo 2012), the subject of performance has continued to challenge management commentators and practitioners for many years (Gibson \& Casser 2005). Performance has been used in some cases to describe concepts such as efficiency, effectiveness, improvement, growth and success and the terms have been used interchangeably (Akbaba 2012). According to Venkatraman and Ramanujam (1986), the treatment of performance in research settings is perhaps one of the most problematic issues confronting the academic researcher, because what performance means or what are appropriate operational definitions are not always clear. As a result of varying perceptions on performance, the concept varies amongst organisations and thus leads to disagreements about whether an organisation is performing or not. In this study, where the focus under consideration is on ECs, performance is regarded as a measurement or indicator that reveals the overall business goals, that is, what the business wants to achieve or the goals it has set (Hove \& Banjo 2015). This definition incorporates both quantitative and qualitative capacity of ECs, including meeting schedule and functional requirements of the project, meeting client satisfaction, building quality and meeting health and safety standards. 


\section{Measuring performance in construction business}

Based on the various definitions of performance construct discussed in the previous section, it can be said that there is no common understanding on which performance could be measured. In South Africa, there has been no scale developed to measure the performance of ECs, yet the performance scale of ECs is fundamental to business executives' planning and control. To guide this study, the performance measurement definitions of Yang et al. (2010) and Neely and Adams (2002) were adopted. The former defines performance measurement as the process through which an organisation establishes the parameters within which programmes, investments and acquisitions reach the desired results, while the latter regards performance measurement as the process of quantifying the efficiency and effectiveness of past actions. Based on the reviewed literature, there were several empirically based performance determinants that were noted, including personal factors, age, gender, life style, business characteristics, creativity and innovation. Other determinants mentioned in the literature include market structures, market orientation culture, CEO remuneration, ownership structure and organisational structure. For example, a recent empirical study by Abor and Biekpe (2007) on Ghanaian SMEs concluded that SMEs with corporate governance structures performed better than their counterparts without them. In another study by Hyder and Lussier (2016), it was found that business planning, proper employee staffing, adequate capital inflows and partnerships are important for the viability and success of small businesses in Pakistan. However, this study was narrowed down and considered the determinants as classified below. These determinants were based on empirical studies and the data analysis used is discussed.

\section{Project implementation}

There are many demands from construction clients who request, among others, quality projects, timely delivery of construction projects and projects that are delivered within budget. The poor performance experienced in the construction industry has attracted the attention of researchers around the world to try and identify the immediate root cause of project delay (Akinsiku \& Akinsulire 2012). For example, a study by Faridi and El-Sayegh (2006) using a questionnaire and inputs from professionals associated with the United Arab Emirates construction industry found that project delays in the United Arab Emirates are caused by delays in the preparation and approval of drawings, inadequate early planning of the project and slowness of owners' decision-making processes. In Saudi Arabia, Assaf and Al-Hejji (2006) discovered that only $30 \%$ of construction projects were completed within the scheduled completion dates and the average time overrun was between $10 \%$ and $30 \%$. The study was based on field survey which was conducted including 23 contractors, 19 consultants and 15 owners. In another empirical study, Lam and Wong (2009) concluded that all the parties involved in a construction project should be responsible for their respective roles at different stages, from the conceptual stage to the final. A review of these studies showed that contractors who avoid delays in their projects perform better than their counterparts who experience project delays. In spite of efforts exerted on ECs' performance in South Africa, many suffer from time delays and cost overruns as well as dissatisfied clients (CIDB 2012). ECs are criticised for poor performance and ineffective delivery of desired goals (CIDB 2012; Mbachu \& Nkado 2007). According to Thwala and Phaladi (2009), such performance is attributed to the complex and unique nature of projects awarded to ECs. In some cases, ECs are awarded dynamic projects, which require continuous change throughout development and execution processes (Haponava \& Al-Jibouri 2010). The effects of project delay include loss of revenue because of slackened production and rentable space (Mukuka, Aigbavboa \& Thwala 2013).

\section{Manpower}

There exists a broad range of literature examining the links between the availability of skills and the performance of firms. The widely reported key manpower links that have an impact on the performance of ECs include shortages of skills and knowledge among construction workers, lack of training in the industry, low productivity and poor team relationships (Mbachu 2012). An empirical study by Carstens (2016) found that there is a distinction between skills and knowledge, with skills being the practical ability or competencies a worker gains from applying the knowledge over time in a hands-on work setting. In another study by Mbachu (2012), it was found that knowledge consists of the ideas, wisdom and information workers acquire through experience, theory and practice, the acquisition of which gives them an ability to understand. Accordingly, a skills shortage could relate to contractors' experience and supervision which have a great impact on project delivery (Mbachu 2012; Otim et al. 2011). A review of Carstens' (2016) and Mbanchu's (2012) empirical studies showed that skills and knowledge could be a source of sustainable competitive advantage and lead to better organisational performance. Although emphasis is on the skills and knowledge that ensure successful project delivery, such skills and knowledge could enable the contractor to run a successful business, remain competitive and achieve sustained growth. An empirical study by Van Wyk (2011) also found that productivity is low in South Africa because skills are not developed in the construction industry nor do employment conditions show respect for people utilised. Another empirical study by Atkinson et al. (2012) found that the employment of casual labour has become the norm in the industry, along with reduced wages, working conditions, remuneration, formal skills development or training and poor quality of life.

\section{Emerging contractors financing}

Access to finance has been cited frequently in the literature as a critical constraint for ECs' performance (e.g. Agwa-Ejon \& Mbohwa 2015; Ali et al. 2010; Nurbani et al. 2011; Otim et al. 2011). In the empirical studies by Agwa-Ejon and Mbohwa (2015) and Thwala and Mvubu (2009), construction firms that have access to bank finances perform better than their competitors who do not have such facilities. These studies 
showed that funding and guarantees are not easily available from SA banks and this affects the performance of ECs. As a result, lack of access to finance disqualifies ECs from meeting guarantee and performance bond requirements leading to cash flow problems and incomplete work and liquidation. Banks are reluctant to deal with ECs unless exorbitant interest rates are paid and through compulsory management services (Thwala \& Mvubu 2009). In other empirical studies by Ligthelm (2011) and Olawale and Garwe (2010), it was shown that small businesses do not have a record of accomplishment to support their bank applications. Even though a study by FinMark (2006) does not directly link access to finance with performance, this study showed $2 \%$ of ECs who could not access bank loans, and this agrees with Foxcroft et al. (2002) who confirmed that $75 \%$ of applications for bank credit by new ECs in South Africa were rejected. In line with empirical studies by Agwa-Ejon and Mbohwa (2015) and Thwala and Mvubu (2009), it can be deduced that if ECs face collateral discrimination from financial institutions and are without finance, they may not survive or grow.

Cash flow management is one critical issue linked to ECs' performance as it creates inadequate cash situation for the business. Poor cash flow management results in inadequate working capital and undermines the sustainability of the ECs. If there is a lack of cash to support a business's day-to-day activities, this could lead to contractors' failure. In an empirical study by Greyling (2012), weak financial and cash flow management were found to affect ECs' business ability to work successfully. Poor cash flow management has been cited in some empirical studies as one of the major causes of failure in small businesses (Greyling 2012). There is an agreement with Truong-Van et al. (2008), whose empirical study of the construction industry in Vietnam found that better management of receivable accounts and careful evaluation of the financial capacity of owners were meaningful factors for measuring strategic performance. This signifies the importance of developing a cash flow forecast that indicates the estimated money flowing into and out of the business over a period of time.

\section{Materials and machinery factors}

Critical shortage of materials in the construction industry has been cited as a major factor in cost overruns (CIDB 2012). Furthermore, while marshalling tools, materials, plant and equipment is a necessary operation, it occupies a large amount of productive working time. An empirical study conducted by Pheng and Chuan (2006) in Singapore showed that contractors who experienced materials shortage had poor performance compared to those who had material and reliable supplies. The results were achieved using a sample of at least 30 projects from both private and public sectors. This study showed that material management factors have a significant impact on labour productivity and construction efficiency. It also showed that worker time could be rendered idle or non-productive if materials and tools are not available at the right time. In many cases, materials are not stored close enough to the work area, leading to double handling.
Another empirical study by Sambasivan and Soon (2007) showed that availability and reliability of materials and machinery affect the project implementation in terms of time and cost overrun. The empirical study of Enshassi et al. (2009) found that excessive waste of material during the application process translated into high production costs and that hindered the profitability and growth of the contractors. Another study by Thwala and Mvubu (2009) concluded that ECs do not have good relationships with suppliers. In a functioning relationship, the material supplier provides credit to the contractor (30-90 day term) and the contractor would pay on time. However, in South Africa, ECs are required by suppliers to pay cash upfront before taking delivery of the material. This kind of relationship exists because ECs often fail to pay on time as a result of capacity or performance constraints. Suppliers are reluctant to extend credit facility to ECs because of perceived risks caused by poor history of ECs' failure to complete projects, systematic contractor payment processing delays, especially for construction works commissioned by the public sector and the potential for material losses because of theft, lack of appropriate storage and mismanagement by ECs.

\section{Quality}

Value to clients is a very complex and subjective issue (CIDB 2011). Quality of construction is a key component of perceived value to clients. ISO 9000: 2000 standard defines quality as the degree to which a set of inherent characteristics fulfils requirement. This definition is in line with Mallawaarachchi and Senaratne (2015) who define quality as meeting the legal, aesthetic and functional requirements of a project. In a survey conducted by CIDB (2011), it was found that there was a significant breakdown in the quality of completed construction works. The survey highlighted that lack of quality is a result of poor or non-sustainable workmanship that exists in the construction industry. This survey was undertaken largely from a client and public perspective and the results demonstrated that quality had an impact on the performance of contractors.

The preference of awarding contracts to ECs has become a subject of concern and controversy to the SA public in general. The concerns and controversy are based on public perception of the quality of work produced by ECs. However, according to Dludla (2018), contractors who produce poor quality projects would falter while those with good quality thrive. There are negative reports in South Africa that most of the infrastructure contracts awarded to ECs were abandoned and the frequent incidences of collapsed Reconstruction and Development Programme (RDP) houses have cast serious doubt on the ability and integrity of ECs. This view is supported by Brandon (2017), who noted complaints about ECs in general and personal accounts of unhappy relations with ECs as too common. Clients of many types often recount stories of how their various building projects have been fraught with difficulty and have ultimately caused financial and emotional hardship. Brandon further states that within one industry the standards according to which various 
participants operate are extremely varied. On one hand, there are sustainable and successful enterprises, regardless of the magnitude of projects undertaken, which are skilled, professional and conduct themselves in such a manner that leads to satisfaction on the part of clients and agents alike. According to Brandon (2017), there are innumerable unscrupulous, unskilled and opportunistic operators whose conduct is totally unacceptable.

\section{Legal and regulatory factors}

There are legal and regulatory compliances that ECs are required to observe, which include health and safety factors and environmental factors. Emerging contractors are also required to be registered with the $\mathrm{CIDB}$, a board that manages their development. However, ECs seem to be trapped in the registration process in which most of them (Grades 1-6) do not have financial means to be registered to the higher financial grades (7-9). Currently, registration is not compulsory, hence, ECs perceive the system of grading as an expensive inconvenience with no value (Greyling 2012). The Health and Safety Act (181 of 1993) provides for the health and safety of persons at work in connection with the use of plant and machinery and the protection of persons, and against hazards to health and safety. The objective of a safety programme is to eliminate losses because of poor working practices that could impact workforce well-being (Windapo \& Oladapo 2012). Accidents during a project can be detrimental to the project in terms of time, cost and the reputation of the company (Chan \& Chan 2004; Sidumedi 2009). In the case of accidents, work may stop in one area of the job, workers' morale may drop and productivity may decline. The number of people who are getting injured or die in the SA construction industry has remained high (Windapo \& Oladapo 2012). These accidents and fatalities have been attributed to noncompliance by contractors with health and safety regulations on construction sites (CIDB 2009; Warwick 2011). The reasons cited in the literature are that some individuals are ignorant of the law or in other cases the contractors take chances (Windapo \& Oladapo 2012). However, Smallwood (2002) has attributed this to lack of knowledge and inadequate training of site workers and contractors regarding the cost of complying with regulations as an unnecessary financial burden (Windapo \& Oladapo 2012). The discussion shows that ECs who do not comply with legal and regulatory factors would be affected and this would have a negative impact on business performance.

\section{Strategic planning}

Ingram (2017) defines strategic planning as the act of creating short-term and long-term plans to guide an organisation to continue and increase its success. Even though data are far from conclusive in establishing the relationship of strategic planning and overall performance of companies, an examination of some published empirical data shows that there is a relative relationship between strategic planning and a company's overall performance. For example, Aldehayyat and Twaissi (2011) studied strategic planning system characteristics in Jordanian small firms and examined its relationship with corporate performance. The empirical research was co-ordinated via a survey of small Jordanian firms. The key findings of this study provided empirical evidence about the involvement of top and line management in planning, the use of strategy tools and techniques. Consequently, the study found a strong positive relationship between strategic planning and company performance. Another empirical study by Jenster and Soilen (2013) examined the relationship between strategic planning and company performance in China and found that better planning had a positive effect on a number of key business performance measures. The study further established that there were differences between different planning activities and company performance. These studies have provided new empirical evidence about the value of strategic planning to company performance from the context of Middle East and China and the evidence could be utilised for the benefit of SA companies.

Despite the importance of strategic planning as confirmed by Aldehayyat and Twaissi (2011) and Jenster and Soilen (2013), ECs have been accused of being 'strategically myopic' and lacking the long-term vision as to where their companies are headed (Thwala \& Phaladi 2009). The concern is that by neglecting strategic planning, ECs may not achieve full performance and growth potentials and survival could be placed at risk. Strategic plans are often formulated on the basis of changes that can be foreseen, which involve selecting business mission and goals, analysing business's external competitive environment to identify opportunities and threats, analysing the internal environment to select strategies that build on the identified strengths and correct weaknesses in order to take advantage of external opportunities and counter external threats.

\section{Hypothesis}

The determinants of ECs' performance as identified from the literature have been presented. These determinants were used as a tool in finding the suitable setting for small businesses that could be used to predict performance. The following assumptions were made:

- Financial factors; manpower factors; supply of materials, equipment and machinery; project implementation; quality factors; legal and regulatory factors; and strategic planning affect ECs' performance.

- Project performance positively affects the overall corporate performance.

- Perceptions of SBEs can affect positively or negatively ECs' performance.

- There is a relationship between company profiles and ECs' performance.

\section{Research methodology}

The study applied both qualitative and quantitative research approaches. The first part of the design was qualitative and in-depth interviews were conducted to define the various thematic areas that led to the development of the quantitative assessment part of the study (phase two). 
The research population was limited to the ECs registered with the CIDB in Gauteng. The ECs that were involved in general building (GB) and civil engineering (CE) were the target population. Gauteng Province was selected based on the level of business confidence recorded during the financial year 2011/2012 (CIDB 2013), when the province appeared the most prosperous in SA, also having a high concentration of construction works. On the basis of accessibility and time factors for the study, urban based ECs were considered. The population of the study comprised $1890 \mathrm{ECs}$, while the unit of analysis was SBEs as representatives of respective ECs. This study introduced a critical incident technique (CIT) as the approach to answering the research question. There are no rules for sample size in qualitative inquiry; rather it depends on what the researcher wants to know, the purpose of the inquiry, what is at stake, what would be useful, what would have credibility and what could be done with available time and resources (Paton 2002). The sample size determination for quantitative data was based on the formulae adapted from Donner, Birkett and Buck (1981). Using the formulae, the sample size required was 385 ECs, but as not all ECs would respond to the questionnaire this necessitated adjustments for attrition rates. It was anticipated that $30 \%$ would not respond to the questionnaires, hence an adjustment for these gave a required sample size of $501 \mathrm{ECs}$ in Gauteng Province.

\section{Research instruments}

\section{The interview guide and data collection procedure}

The interview guide had seven open-ended questions that were administered and the variables were taken from reviewed literature. The guide was structured in a manner that critical incidents would be collected. SBEs were requested to identify incidents that led to high or low performance in construction; however, as the interviews were verbal reports only, the key informants' responses were subject to common problems of bias, poor recall and poor or inaccurate articulation.

\section{The questionnaire}

Based on the qualitative results, a questionnaire was developed to evaluate the perceptions of SBEs at a large scale. The questionnaire comprised of six sections. In Section A, the demographic characteristics of respondents were requested and the information gathered consisted of gender, age group, ethnicity, construction experience, disability status and level of education. In Section B, data on the business profile, including location, age of business, CIDB grading, manpower size, business ownership, service provided and construction projects undertaken, were collected. Section C requested data about SBEs' perceptions on determinants of business performance in the construction industry. Section D requested information about the perception regarding overall business performance over the previous 3 years, while Section E measured the perception on project performance. The last section, F, asked the respondents to highlight their perceptions on how to improve the performance of SA ECs.
All the variables tested were found from the literature reviewed. The validity and reliability of the questionnaire were tested and the results showed that the items in the instrument were relevant for the study. The primary data were collected from the CEOs, chief financial officers, managing directors, contract directors and marketing directors as representatives of selected ECs.

\section{Data analysis}

To assess the perceived determinants of ECs' performance in Gauteng Province, STATA version 12 was used to carry out univariate analysis and multiple regression analysis, the benefits of which included its ability to provide descriptive statistics, cross-tabulation, frequencies, prediction for numerical outcomes and prediction for identifying groups, and factor analysis. Multiple linear regression of the various hypothesised predictors against the outcome variable was carried out in order to control for any potential confounders and to come up with a linear model that related all the significant factors to the outcome, ECs' performance.

\section{Research findings and discussions Qualitative findings}

The profile of SBEs interviewed was assessed and the results indicated that $17 \%$ of the respondents were females, participants had an average age of 44 years and $83 \%$ were black people. No disability status was reported. The highest level of formal education ranged from non-matric (33\%), matric $(50 \%)$ to diploma level $(17 \%)$. They were builders, concrete reinforces and general contractors. The profile of the key informants is summarised in Table 1.

\section{Critical incidents identified}

Based on the interviews conducted with key informants, the key findings showed financial factors, manpower, materials, machinery and equipment, project implementation, quality of work, legal and environmental factors and strategic planning as the main determinants that should be addressed when running contracting businesses. Furthermore, within these determinants critical incidents were identified and are summarised in Appendix 1. The incidents are summarised according to score (agreed or disagreed), where the score of 1 (agreed) represents 100\% of respondents who confirmed the incident and the score of 0.17 (disagreed) represents $17 \%$ of respondents who disagreed that the incident had an impact on ECs' performance.

\section{Quantitative findings}

A total of 501 respondents were targeted for the interviews and 433 responded, giving a response rate of $86 \%$. The high response rate was attributed to the combined effects of survey techniques that included face-to-face and telephonic interviews. The demographic characteristics of the respondents are summarised in Table 2. 
TABLE 1: Profile of key informants.

\begin{tabular}{|c|c|c|c|c|c|c|}
\hline \multirow[t]{2}{*}{ Study area } & \multicolumn{6}{|c|}{ Responses received } \\
\hline & Contractor A & Contractor B & Contractor C & Contractor D & Contractor $\mathrm{E}$ & Contractor $\mathrm{F}$ \\
\hline Gender & Female & Male & Male & Male & Male & Male \\
\hline Age group & 58 years & 61 years & 28 years & 46 years & 38 years & 34 years \\
\hline Ethnic group & Black & Black & Black & White & Black & Black \\
\hline Disability & None & None & None & None & None & None \\
\hline Qualification & Non-matric & Non-matric & Matric & Matric & Teaching diploma & Matric \\
\hline Profession & Builder & Builder & Reinforcement & Builder \& reinforcement & General Contractor & Builder \& reinforcement \\
\hline Functional role & Chief executive officer & Owner & Contract manager & Owner & Managing director & Owner \\
\hline Province & Gauteng & Gauteng & Gauteng & Gauteng & Gauteng & Gauteng \\
\hline No. of years & 2 years & 2 years & 3 years & 1 years & 3 years & 3 years \\
\hline CIDB grading & Grade 2 & Grade 2 & Grade 2 & Grade 2 & Grade 2 & Grade 2 \\
\hline Company size & 35 unskilled & 45 unskilled 2 skilled & $\begin{array}{l}1 \text { skilled } \\
15 \text { unskilled }\end{array}$ & $\begin{array}{l}2 \text { foremen } \\
52 \text { unskilled }\end{array}$ & 15 unskilled & $\begin{array}{l}12 \text { brick layers } \\
24 \text { labourers }\end{array}$ \\
\hline ECs' profile & Male and Female & Male & Male & Male & Male & Male \\
\hline Service provided & Civil engineering & General building & $\begin{array}{l}\text { Civil engineering and } \\
\text { general building }\end{array}$ & $\begin{array}{l}\text { Civil engineering and } \\
\text { general building }\end{array}$ & $\begin{array}{l}\text { Civil engineering and } \\
\text { general building }\end{array}$ & General building \\
\hline Construction projects & $\begin{array}{l}\text { Government and } \\
\text { private }\end{array}$ & $\begin{array}{l}\text { Government and } \\
\text { private }\end{array}$ & $\begin{array}{l}\text { Government and } \\
\text { private }\end{array}$ & $\begin{array}{l}\text { Government and } \\
\text { private }\end{array}$ & $\begin{array}{l}\text { Government and } \\
\text { private }\end{array}$ & $\begin{array}{l}\text { Government and } \\
\text { private }\end{array}$ \\
\hline
\end{tabular}

TABLE 2: Distribution of respondents by demographic characteristics.

\begin{tabular}{|c|c|}
\hline Characteristics & Frequency $(\%) N=433$ \\
\hline \multicolumn{2}{|l|}{ Gender } \\
\hline Male & 65 \\
\hline Female & 35 \\
\hline \multicolumn{2}{|l|}{ Age (years) } \\
\hline$<30$ & 15 \\
\hline $30-49$ & 66 \\
\hline $50+$ & 19 \\
\hline \multicolumn{2}{|l|}{ Ethnicity } \\
\hline Black & 67 \\
\hline Indian & 12 \\
\hline White & 17 \\
\hline Mixed race & 5 \\
\hline \multicolumn{2}{|l|}{ Disability status } \\
\hline Disabled & 8 \\
\hline Not disabled & 92 \\
\hline \multicolumn{2}{|c|}{ Job experience (years) } \\
\hline$<5$ & 12 \\
\hline $5-10$ & 40 \\
\hline $11-20$ & 44 \\
\hline$>20$ & 4 \\
\hline \multicolumn{2}{|c|}{ Formal education } \\
\hline No formal & 13 \\
\hline Non-matric & 11 \\
\hline Matric & 32 \\
\hline Post-matric & 27 \\
\hline Degree & 17 \\
\hline
\end{tabular}

\section{Reliability and validity analysis}

The questionnaire had subscales designed to measure the various factors that were hypothesised as affecting ECs' performance. As the responses of different SBEs would be used to draw conclusions about ECs' performance, the subscales were needed to have good reliability and validity. Reliability in this case was assessed through internal consistency of the subscales. Coefficient alpha (Cronbach's alpha) gave an estimate of the reliability of the scale. The subscales were also tested for validity, that is, the extent to which they successfully measured the construct. Item analysis was used to clean up the subscales, item-by-item, in
TABLE 3: Reliability and validity analysis.

\begin{tabular}{lccc}
\hline Construct & Cronbach's alpha & Number of items & Items dropped \\
\hline Financial factors & 0.869 & 8 & None \\
Manpower factors & 0.828 & 6 & C4.5 \& C4.8 \\
Supply of materials, etc. & 0.896 & 6 & None \\
Project implementation & 0.881 & 5 & C6.6 \& C6.7 \\
Quality factors & 0.848 & 7 & None \\
Legal and regulatory issues & 0.934 & 8 & None \\
Strategic planning & 0.926 & 5 & None \\
Project performance & 0.927 & 9 & None \\
Organisation performance & 0.944 & 8 & None \\
Performance improvement & 0.943 & 8 & F12.1 \\
\hline
\end{tabular}

order to maximise the reliability and validity. After item analysis only the good items were retained in each subscale for further analysis. The results of the validity and reliability of the instruments used are presented in Table 3.

From Table 3 data, it is clear that the Cronbach's coefficients obtained are all sufficiently large (> 0.80), suggesting consistency of responses for all the subscales after dropping the identified items, the manpower factors (C4.5 and C4.8), project implementation (C6.6 and C6.7) and performance improvement (F12.1).

\section{Confirmatory factor analysis}

Correlation analysis was conducted to explore the relationships between variables and to check the presence of multi-linearity. Table 4 shows the correlation coefficients among the variables that were used in the factor analysis. They indicate good convergence and discriminant validity of the factor analysis, which demonstrates that the variables loaded on particular factors correlate significantly. The highest correlation is between ECs' performance and project performance $(0.4866)$, followed by the correlation between strategic planning and project implementation (0.3944). The lowest correlation of 0.0386 between project implementation and project performance shows a weak correlation between the two performance items. 
TABLE 4: Correlation analysis: Emerging contractors' performance, strategic planning, project implementation and project performance.

\begin{tabular}{|c|c|c|c|c|}
\hline Variables & Emerging contractors' performance & Strategic planning & Project implementation & Project performance \\
\hline Emerging contractors' performance & 1 & 0.2106 & 0.2668 & 0.4866 \\
\hline Strategic planning & 0.2106 & 1 & 0.3944 & 0.0438 \\
\hline Project implementation & 0.2668 & 0.3944 & 1 & 0.0386 \\
\hline Project performance & 0.4866 & 0.0438 & 0.0386 & 1 \\
\hline
\end{tabular}

TABLE 5: Results of univariate analysis.

\begin{tabular}{lccc}
\hline Total factor performance & Coefficient & $95 \% \mathrm{Cl}$ & $\boldsymbol{p}$ \\
\hline Financial factors & 0.176 & $(0.069,0.282)$ & 0.001 \\
Strategic planning & 0.273 & $(0.153,0.393)$ & $<0.001$ \\
Supply of materials & 0.162 & $(0.055,0.268)$ & 0.003 \\
Legal and regulatory factors & 0.149 & $(0.069,0.236)$ & $<0.001$ \\
Quality & 0.101 & $(-0.018,0.220)$ & $0.096 \mathrm{NS}$ \\
Manpower & 0.285 & $(0.163,0.408)$ & $<0.001$ \\
Project implementation & 0.368 & $(0.242,0.494)$ & $<0.001$ \\
Project performance & 0.482 & $(0.400,0.564)$ & $<0.001$ \\
\hline
\end{tabular}

$\mathrm{Cl}$, confidence interval; NS, not significant.

The extent to which the research hypotheses were tested is presented in this section.

Hypothesis 1: Financial factors; manpower factors; supply of materials, equipment and machinery; project implementation; quality factors; legal and regulatory factors; and strategic planning affect ECs' performance.

According to univariate analysis (simple linear regression) tested in Table 5 based on the perceptions of the respondents, the following factors were found to significantly affect ECs' performance $(p<0.005)$ : financial factors; strategic planning; supply of materials, equipment and machinery; legal and regulatory factors; manpower factors; project implementation (delays) and actual project performance. However, quality factors were found non-significant $(p>0.005)$; it was greater than $5 \%$ level of significance. The results were further tested using multiple linear regression method.

\section{Multiple linear regressions}

Financial factors, manpower factors, supply of materials, and legal and regulatory factors found to be statistically insignificant were dropped and not reported in the results of multiple linear regression analysis. The scores were based on the Likert scale, from which all items for each area were added to give the minimum and maximum scores expected. These scores form a continuous score which was used in the modelling of the data for the regression. Table 6 indicates a summary of the regression analysis for statistically significant factors only.

The multiple linear regression models below indicate the remaining significant factors based on the calculation of STATA version 12. The estimated total factor of performance or predicted ECs' performance was 1.97.

Perceived emerging contractors performance $=1.97+0.117$ Strategic Planning +0.345 Project Implementation +0.488 Project Performance.

where (model interpretation):
TABLE 6: Results of multiple linear regression analysis.

\begin{tabular}{lccc}
\hline Total factor performance & Coefficient & $95 \% \mathrm{Cl}$ & $\boldsymbol{p}$ \\
\hline Strategic planning & 0.117 & $(0.007,0.227)$ & 0.037 \\
Project implementation & 0.345 & $(0.228,0.462)$ & $<0.001$ \\
Project performance & 0.488 & $(0.410,0.565)$ & $<0.001$ \\
\hline
\end{tabular}

$\mathrm{Cl}$, confidence interval.

The value of 1.97 in the model represents the attainable performance (moderate) that would be achieved by ECs when variables such as strategic planning, project implementation and project performance are excluded.

The value of 0.117 indicates that a unit increase in strategic planning causes a 0.117 unit increase in ECs' performance.

The value 0.345 shows that a unit increase in project implementation results in a 0.345 unit increase in ECs' performance.

The value 0.488 shows that a unit increase in project performance results in a 0.488 unit increase in ECs' performance.

Hypothesis 2: Project performance positively affects the overall corporate performance.

According to the regression model established above, project performance positively affects emerging contractors' performance (positive coefficient of 0.488). As indicated in the model, project management receives direction and support from executive management and also acquires resources from the asset management portion of the organisation. Thus, the success of a project hinges on the performance of project management, with emphasis on the achievement of time, cost and quality targets (and achievement of health and safety requirements.

Hypothesis 3: Perceptions of SBEs can affect positively or negatively ECs' performance.

Using the Likert scale, the SBEs were asked to agree or disagree with each statement on the questionnaire and the items were added to give the minimum and maximum scores expected. The scores were summed to measure the SBEs' overall perception. Specifically, the study measured the perceptions from a large number of statements, each of which was considered relevant to the perception being measured and was believed to reflect an agreement or disagreement with that attitude. Thus, the perceptions of SBEs were defined as the sum of all the responses from the section on perceptions on determinants of ECs' performance. These scores form a continuous score which was used in the modelling of the data for the regression. Investigating the correlation of perceptions and ECs' 
performance indicated that perceptions of SBEs positively affect $(r=0.254)$ their ECs' performance. The hypothesis was tested by calculating the correlation coefficient between SBEs perceptions and ECs' performance, and the coefficient calculated using STATA version 12 showed a positive coefficient of $r=0.254$.

Hypothesis 4: There is a relationship between company profiles and ECs' performance.

Regression analysis of ECs' performance against the number of years the business has been operating indicates that there is no significant relationship $(p=0.126)$ between the two. Upon carrying out regression analysis, it is noted that there is no significant relationship between company performance and the size of the company in terms of manpower ( $p=$ 0.1895 ) and in terms of skilled workforce the relationship was also insignificant $(p=0.625)$. This may possibly be explained by the observation that there is an insignificant number of skilled workers in each company $(\geq 3)$.

The variable ECs' performance was converted to a categorical variable in order to carry out tests of association. The chisquared tests of association carried out indicated that there is no significant relationship between ECs' performance and race $(p=0.261)$, gender ownership $(p=0.804)$ and disability status $(p=0.255)$. However, there is a significant relationship between the age of owner and ECs' performance ( $p=0.000)$ and the correlation coefficient is -0.1899 , indicating that with increasing age performance decreases.

There is no significant relationship between ECs' performance and the type of services offered, civil engineering $(p=0.996)$ and general building $(p=0.560)$.

There is no significant relationship between ECs' performance and the type of project, government $(p=0.777)$ and private development ( $p=0.751$ ). The summary of the hypotheses results is presented in Table 7.

\section{The structure of the proposed conceptual performance prediction model}

The research findings (qualitative and quantitative) were synthesised and analysed. The combination enhanced validity and reliability of the results and extended the scope and depth of understanding the subject. Based on the

\begin{tabular}{lll} 
TABLE 7: Summary of results. & \\
\hline No. & Hypotheses & Findings \\
\hline H1 & $\begin{array}{l}\text { Financial factors; manpower factors; supply of materials, } \\
\text { equipment and machinery; project implementation; } \\
\text { quality factors; legal and regulatory factors; and strategic } \\
\text { planning affect emerging contractors' performance. }\end{array}$ & Supported \\
H2 & $\begin{array}{l}\text { Project performance positively affects the overall } \\
\text { corporate performance. }\end{array}$ & Supported \\
H3 & $\begin{array}{l}\text { Perceptions of small business executives can affect } \\
\text { positively or negatively their business performance. }\end{array}$ & Supported \\
H4 & $\begin{array}{l}\text { There is a relationship between small business executive } \\
\text { profiles and business performance. }\end{array}$ & Not supported \\
\hline
\end{tabular}

synthesis of results, the proposed model was developed on the data generated from the perceptions of SBEs. The model is divided into four stages: stage 1 is the strategic planning, stage 2 is project implementation, stage 3 is project performance and stage 4 is performance prediction as illustrated in Figure 1.

The model predicts that in order for ECs to become profitable and sustainable in the construction business, SBEs must continually increase or put more effort on the three determinants identified, which would result in desired business outcomes and stakeholder expectations (community, government, customers and investors).

\section{Benefits and limitations of the model}

Model diagnostic tests were carried out to establish whether all the assumptions for fitting a linear regression had been satisfied. Where appropriate, correlation analysis and the chi-squared test of association were used to investigate relationships between variables. Based on the tests made, the model provides a representation that helps set a benchmark for predicting the performance of a construction business, and this would certainly benefit ECs, clients, community as well as policymakers. Using this model, SBEs can predict whether the project is on schedule, ahead of schedule or behind schedule, based on the management and coordination of project implementation activities. Using that information, the project manager is expected to provide feedback to leadership. The model, therefore, expands our understanding of the theoretical principles in explaining ECs' performance.

However, the model is a mere tool that can guide SBEs in running a construction business and cannot be considered as the most appropriate guarantee of optimal success of ECs, considering the perceived SBEs' resistance and lack of ability to use it, and the resources required to implement it. The model should be regarded as part of the solution to predict ECs' performance. The chances of improving the success and performance of the organisations are high, should ECs adapt the model.

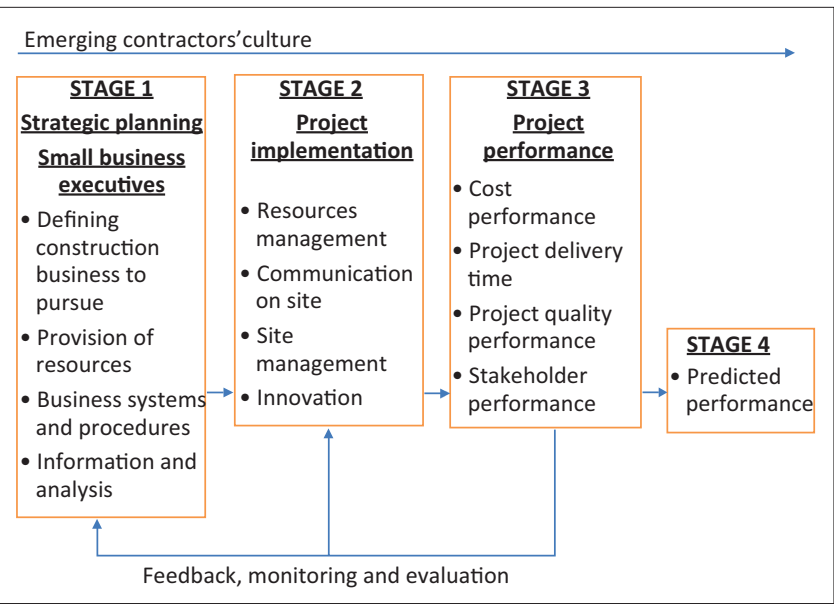

FIGURE 1: The structure of the performance prediction model. 


\section{Conclusion}

The study was set to assess the critical incidents encountered by ECs and the determinants of performance for those registered with CIDB. Using mixed research techniques and content analysis of primary and secondary sources, a userfriendly and policy-relevant performance model was developed based on a perceptual analysis of the emerging contractors. Furthermore, a new set of significant determinants of performance as perceived by SBEs in South Africa's (Gauteng Province) construction industry was established.

\section{Practical implications}

Based on the findings of this study, ECs should pay close attention to their particular business circumstance before embarking on the execution of construction projects in order to better understand the implications of their actions. Particular attention should be given to the following implications.

\section{Financial implication}

As long as access to finance remains a challenge to ECs, their performance in terms of growth, profitability, job creation and economic growth, among other performance indicators, will remain weak and they would not be able to adequately plan. It is therefore important for executives to be innovative and raise finance for their businesses.

The implication on delayed payments is that projects would not be completed on time when late payments persist; hence, the efforts by government in promoting ECs would be a waste of time and energy. Therefore, clients need to guarantee adequate funding before commencement of projects.

\section{Manpower implication}

The results show that lack of skills and restrictive labour regulations have a negative effect on the performance of ECs in terms of productivity and job creation. Thus, if skills are not improved, labour productivity would remain low, and if labour laws are not relaxed, job creation would be reduced or rather existing jobs would be lost.

\section{Project implementation implication}

The results demonstrated that SBEs place great emphasis on project implementation at the expense of organisation. They put little effort into business planning, but much into project implementation. The implication is that the growth and profitability of ECs would remain low if there were no link between projects and business activities. Emerging contractors are concentrating on project implementation because there is immediate project income to be realised. They must connect projects to business planning and through long-term business planning the sustainability of the business would be realised.

\section{Quality implication}

There are quality challenges that emerged, especially in the literature relating to the performance of ECs. The poor performance in quality for client, consultants and community satisfaction impacts heavily on ECs' reputation in the industry.

\section{Legal and environmental implication}

Emerging contractors lack commitment to a culture that promotes commitment to comply with health and safety requirements in the construction industry. If this culture is not corrected, increased costs to the business in terms of rework, lost time, disruption, productivity loss and loss of much needed skills would be on the increase.

\section{Strategic planning implication}

Small business executives need to understand the practice of strategic planning in a manner that would lead to higher ECs' performance. In the absence of a proper and comprehensive construction plan, parties to the business cannot be informed or held accountable for the timing and duration of their planned activities.

\section{Limitations of the study}

There are limitations that emerged during the development of the interview guide, the questionnaire and during the data collection and analysis phases. Thus, the following limitations should be kept in mind when interpreting the results of this study:

- The variables selected for the developed instruments may not be complete in terms of factors affecting ECs' performance.

- The data generated in this study are limited to CIT and this survey technique has not been used in the construction industry before.

- The study relies on perceptions of SBEs, which might have been influenced by perceptual biases and cognitive limitations.

\section{Future research}

There are a number of future researches that could be conducted in continuation of this research. The scope of the model was limited to Gauteng-based ECs and needs to be validated by expanding its scope to other SA provinces and regional countries.

\section{Acknowledgements}

The authors would like to thank the CIDB management for allowing G.H. to utilise their database for his study and the small business executives for participating in the study and providing valuable inputs. We also thank Professor Simbarashe Rusakaniko of the University of Zimbabwe who shared so much knowledge with the authors. This article is based on the doctoral study of G.H. that revisited the discourse on small business performance in general and specifically explored the perceptions of Gauteng-based executives of small construction firms on determinants of performance in the sector. 


\section{Competing interests}

The authors declare that they have no competing interests with regard to the writing of this article.

\section{Authors' contributions}

Both G.H. and A.B. conceptualised the study and then G.H. did the research as part of his doctoral studies. G.H. wrote up the article and dealt with comments from the reviewers and the Editorial Board.

\section{References}

Abor, J. \& Biekpe, N., 2007, 'Corporate governance, ownership structure and performance of SMEs in Ghana: Implications for financing opportunities', Corporate Governance 7(3), 288-300. https://doi.org/10.1108/14720700710756562

Agwa-Ejon, J. \& Mbohwa, C., 2015, 'Financial challenges faced by SMMEs in Gauteng South Africa', International association for management of technology IAMO 2015 Conference proceedings, Johannesburg, South Africa, pp. 520-534.

Akbaba, A., 2012, 'Business performance of small tourism enterprises: A comparison among three sub-sectors of the industry', An International Journal of Tourism and Hospitality Research 23(2), 177-195. https://doi.org/10.1080/13032917.2012.66 2907

Akinsiku, O.E. \& Akinsulire, A., 2012, 'Stakeholders' perception of the causes and effects of construction delays on project delivery', Journal of Construction Engineering and Project Management 2(4), 25-31. https://doi.org/10.6106/ JCEPM.2012.2.4.025

Aldehayyat, J.S. \& Twaissi, N., 2011, 'Strategic planning and corporate performance relationship in small business firms: Evidence from a Middle East Country Context', International Journal of Business and Management 6(8), 255-263. https://do org/10.5539/ijbm.v6n8p255

Ali, A.S., Smith, A., Pitt, M. \& Choon, C.H., 2010, 'Contractors' perception of factors contributing to project delay: Case studies of commercial projects in Klang Valley, Malaysia', Journal of Design and Built Environment 1, 43-57.

Assaf, S.A. \& Al-Hejji, S., 2006, 'Causes of delay in large construction projects', International Journal of Project Management 24(7), 349-357. https://doi. org/10.1016/j.ijproman.2005.11.010

Atkinson, D., Ntema, L., Pappin, M., Gouveia, A. \& Venter, A., 2012, 'Review of the efficiency and effectiveness of past and on-going SME development initiatives in the Free State Province', International Labour Organization, viewed 15 January the Free State Province', International Labour Organization, viewed 15 January 2018, from http://www.ilo.org/

Beatham, S., Anumba, C., Thorp, T. \& Hedges, I., 2004, 'KPIs: A critical appraisal of their use in construction', Benchmarking: An International Journal 11(1), 93-117.

Brandon, A., 2017, The master builder - Perceptions about our members, Master Builders KwaZulu-Natal, viewed 03 November 2017, from http://www. masterbuilders.co.za/news/2009/july/rationale_for_best_practice initiative.htm

Buys, F. \& Daluxolo, L., 2012, 'The potential of built environment professionals' contribution towards emerging contractor development', Acta Structilia 19(2), $74-89$

Carstens, A., 2016, 'Cultivating the soft skills of future construction managers through restorying construction workers' career narratives', The Journal for Trans-Disciplinary Research in Southern Africa 12(1), 1-9. https://doi.org/10.4102/td.v12i1.335

Census, 2011, Census in brief, Report No. 03-01-41, Statistics South Africa, Pretoria viewed 15 August 2017, from http://www.statssa.gov.za/census2011/Products/ Census_2011_Census_inbrief.pdf

Chan, A.P.C. \& Chan, A.P.L., 2004, 'Key performance indicators for measuring construction success', Benchmarking: An International Journal 11(2), 203-221. https://doi.org/10.1108/14635770410532624

Construction Industry Development Board (CIDB), 2009, SA Contractor Development Programmes: Status Quo Report, CIDB, Pretoria.

Construction Industry Development Board (CIDB), 2011, Financial modelling options for contractor support and development, $\mathrm{CIDB}$, Pretoria.

Construction Industry Development Board (CIDB), 2012, The construction industry as a vehicle for contractor development and transformation, CIDB, Pretoria. ISBN 978-0-621-40773-0.

Construction Industry Development Board (CIDB), 2013, Subcontracting in the SA construction industry; Opportunities for development, CIDB, Pretoria. ISBN 978-0 620-56039-9.

Dludla, S., 2018, Mashaba wants contractors probed over houses damaged in Johannesburg storm, viewed 15 January 2018, from https://www.iol.co.za/news/ south-africa/gauteng/

Dlungwana, S., Kandie, W. \& Ngassam, E.K., 2009, 'Enhancing the quality of service delivered by South Africa's Small Contractors through e-Mentoring', Conference ICL 2009, Villach, Austria, September 23-25, pp. 398-406.

Donner, A., Birkett, N. \& Buck, C., 1981, 'Randomization by cluster. Sample size requirements and analysis', American Journal of Epidemiology 114(6), 906-914. https://doi.org/10.1093/oxfordjournals.aje.a113261
Enshassi, A., Mohamed, S. \& Abushaban, S., 2009, 'Factors affecting the performance of construction projects in the Gaza Strip', Journal of Civil Engineering and Management 15(3), 269-280. https://doi.org/10.3846/1392-3730.2009.15.269-280

Faridi, A. \& El-Sayegh, S., 2006, 'Significant factors causing delay in the UAE construction industry', Construction Management and Economics 24(11), 1167-1176. https://doi.org/10.1080/01446190600827033

FinMark Trust, 2006, FinScope small business survey report, viewed 26 October 2017 from http://www.finmarktrust.org.za

Foxcroft, M., Wood, W.K., Herrington, M. \& Segal, N., 2002, Global Entrepreneurship Monitor SA Report, viewed 07 January 2010, from http://www.gbs.nct.ac.za/ gbswebb/userfiles/gemsouthafrica2000pdf

Gauteng Online, 2005, Growth and Development Strategy - Gauteng, viewed 15 August 2014 , from www.gautengonline.gov.za/.../Growth\%20and\%20Development\%20S trategy.pdf

Gibson, B. \& Cassar, G., 2005, 'Longitudinal analysis of relationships between planning and performance in small firms', Small Business Economics 25(3), 207-222. https://doi.org/10.1007/s11187-003-6458-4

Greyling, E., 2012. South Africa SME observatory: Opportunities for employment creation through SME Development in the construction sector, Free State. International Labour Organisation, Switzerland.

Haponava, T. \& Al-Jibouri, S., 2010, 'Influence of process performance during the construction stage on achieving end-project goals', Construction Management and Economics 28(8), 853-869. https://doi.org/10.1080/014461 93.2010.487535

Herrington, M., Kew, J. \& Kew, P., 2010, Tracking entrepreneurship in South Africa: A GEM perspective, SAGEM Report, Graduate School of Business, Cape Town.

Hove, G. \& Banjo A.O., 2015, 'Performance in the construction industry-A conceptua and theoretical analysis', Open Journal of Business Management 3, 177-184. https://doi.org/10.4236/ojbm.2015.32017

Hyder, S. \& Lussier, R.N., 2016, 'Why businesses succeed or fail: A study on small businesses in Pakistan', Journal of Entrepreneurship in Emerging Economies 8(1), 82-100. https://doi.org/10.1108/JEEE-03-2015-0020

Ingram, D., 2017, Why is the implementation of projects important to strategic planning and the project manager? viewed 12 December 2017, from http:// smallbusiness.chron.com/implementation-projects-important-strategicplanning-project-manage

Jenster, P. \& Soilen, K.S., 2013. 'The relationship between strategic planning and company performance - A Chinese perspective', Journal of Intelligence Studies in Business 1, 15-30.

Kaplan, R.S. \& Norton, D.P., 1992, 'The balanced scorecard measures that drive performance', Harvard Business Review 71-79, viewed 15 January 2018, from http://planuba.orientaronline.com.ar/wp-content/uploads/2010/03/harvard business-review-kaplan-norton-the-balanced-scorecard-measures-that-driveperformance.pdf

Ladzani, L., Smith, N. \& Pretorious, L., 2012, 'Using leadership and strategic planning functions to improve management performance: The progress made by small, medium and micro enterprises (SMMEs) in the Province of Gauteng', African Journal of Business Management 6(11), 3988-3999.

Lam, P.T.I. \& Wong, F.W.H., 2009, 'Improving building project performance: How buildability benchmarking can help', Construction Management and Economics 27, 41-52. https://doi.org/10.1080/01446190802570498

Ligthelm, A., 2011, 'Survival analysis of small informal businesses in South Africa, 2007-2010', Eurasian Business Review 1(2), 160-179.

Mallawaarachchi, H. \& Senaratne, S., 2015, 'Importance of quality for construction project success', 6th International conference on structural engineering and construction management 2015, Kandy, Sri Lanka, December 11-13, pp. 84-89.

Marx, H.J., 2012, 'Construction industry indicators affecting contractors', Journal for the Advancement of Performance Information and Value 4(1), 119-132.

Mbachu, J., 2012, 'Knowledge and skills required for contractors' performance in construction project delivery: An exploratory study of the up-skilling needs of the New Zealand contractors', Proceedings of Waber Conference, Abuja, Nigeria, July 24-26, 2012, pp. 859-869.

Mbachu, J. \& Nkado, R., 2007, 'Factors constraining successful building project implementation in SA', Construction Management and Economics 25(1), 39-54.

Mukuka, M.J., Aigbavboa, C.O. \& Thwala, W.D., 2013, Construction professionals perception on the causes and effects of project delay in Lusaka, Zambia, viewed 23 May 2014, from http://ujdigispace.uj.ac.za/handle

Neely, A. \& Adams, C., 2002, 'The performance prism perspective', Journal of Cost Management 15(1), 7-15.

Nurbani, H., Chin, S., Yeow, J. \& Ashikin, N., 2011, 'Financial constraints and opportunities of micro entrepreneurs: A theoretical framework', 26-28 November 2010 International Conference on Business and Economics Research, vol. 1, IACSIT Press, Kuala Lumpur, Malaysia, pp. 165-168.

Ofori, G., 1991, 'Programmes for improving the performance of contracting firms in developing countries: A review of approaches and appropriate options', Construction ManagementandEconomics9(1), 19-38. https://doi.org/10.1080/01446199100000003

Olawale, F. \& Garwe, D., 2010, 'Obstacles to the growth of new SMEs in SA: A principal component analysis approach', African Journal of Business Management 4(5), 729-738.

Otim, G., Alinaitwe, H.M., Tindiwensi, D. \& Kerali, A.G., 2011, 'The causes and impact of uncompleted buildings; studies in Kampala City', Second International Conference on Advances in Engineering and Technology, viewed 14 May 2014, from http://news.mak.ac.ug/documents/Makfiles/aet2011/Otim.pdf 
Patton, M., 2002, Qualitative research and evaluation methods, 3rd edn., Sage, Thousand Oaks, CA.

Pheng, L.S. \& Chuan, Q.T., 2006, 'Environmental factors and work performance of project managers in the construction industry', International Journal of Project Management 24, 24-37. https://doi.org/10.1016/j.jproman.2005. 06.001

Rust, F.C. \& Koen, R., 2011, 'Positioning technology development in the SA construction industry: A technology foresight study', Journal of the SA Institution of Civil Engineering 53(1), 2-8.

Sambasivan, M.A. \& Soon, Y.W., 2007, 'Causes and effects of delays in Malaysian construction industry', International Journal of Project Management 25(5), 517-526. https://doi.org/10.1016/j.ijproman.2006.11.007

Sidumedi, K.S., 2009, An investigation into the relationship between the corporate culture of SA construction firms and performance, viewed 16 May 2014, from http://wiredspace.wits.ac.za/handle/10539/7942

Smallwood, J.J., 2002, 'The influence of health and safety (H \& S) culture on H \& S performance', in D. Greenwood (ed.), Proceedings of the 18th Annual ARCOM Conference, University of Northumbria, September 2-4, 2002, pp. 217-226.

The Health and Safety Act, as amended by the Occupational Health and Safety Amendment Act (181 of 1993).
Thwala, W.D. \& Mvubu, M., 2009, 'Problems facing small and medium size contractors in Swaziland', Journal Service Science and Management 2, 353-361. https://doi. org/10.4236/jssm.2009.24042

Truong-van, L., Kim, S., Cao, H. \& Park, Y., 2008, 'Performance measurement of construction firms in developing countries', Construction Management and Economics 26(4), 373-386. https://doi.org/10.1080/01446190801918706

Van Wyk, L., Kolev, M., Osburn, L., de Villers, A. \& Kimmie, Z., 2011, The employment aspects of energy related improvements in construction in South Africa, International Labour Organisation, Switzerland.

Venkatraman, N. \& Ramanujam, V., 1986, 'Measurement of business performance in strategy research: A comparison of approaches', Academy of Management Review 11, 801-814.

Warwick, J., 2011, Building industry safety needs to be of stellar standard, viewed 14 September 2014, from http://www.crown.co.za/new/2011/July/building industry_safety_needsto_be-ofstellar_standard.htm

Windapo, A. \& Oladapo, A., 2012, 'Determinants of construction compliance with health and safety regulations in SA', paper presented at 28th Annual ARCOM Conference, Association of Researchers in Construction Management, Edinburgh, UK, 3rd-5th September 2012, pp. 433-444.

Yang, H., Yeung, J.F.Y., Chan, A.P.C., Chiang, Y.H. \& Chan, D.W.M., 2010, 'A critical review of performance measurement in construction', Journal of Facilities Management 8(4), 269-284. https://doi.org/10.1108/14725961011078981 


\section{Appendix 1}

APPENDIX 1: Summary of critical incidents identified.

\begin{tabular}{|c|c|c|}
\hline \multirow[t]{2}{*}{ Financial category } & \multicolumn{2}{|c|}{ Respondents' perceptions } \\
\hline & Agreed score & Disagreed score \\
\hline Lack of collateral and assets because of poor credit ratings & 1.00 & 0.00 \\
\hline Late payments towards completed work by clients & 1.00 & 0.00 \\
\hline Poor cash flow management and budget control & 1.00 & 0.00 \\
\hline Tender pricing pressure from main contractors & 0.83 & 0.17 \\
\hline $\begin{array}{l}\text { Payment problems experienced as a result of rework relating to faults (e.g. project design errors, formwork errors, } \\
\text { plumbing errors, mechanical and electrical works faults) }\end{array}$ & 0.67 & 0.33 \\
\hline Payment of performance guarantee/retention & 0.50 & 0.50 \\
\hline High registration and annual renewal fees & 0.33 & 0.67 \\
\hline Total score on financial incidents & 4.93 & 2.17 \\
\hline \multicolumn{3}{|l|}{ Manpower category } \\
\hline Shortage of experienced and competent labour force & 1.00 & 0.00 \\
\hline High rate of labour disputes and strikes & 1.00 & 0.00 \\
\hline $\begin{array}{l}\text { Cumbersome administrative tasks, such as unemployment Insurance fund (UIF) workmen's compensation, skills } \\
\text { development levy }\end{array}$ & 1.00 & 0.00 \\
\hline Low labour productivity because of employee dissatisfaction and absenteeism & 1.00 & 0.00 \\
\hline The skills obtained from higher education and the skills required in the construction industry do not match & 0.83 & 0.17 \\
\hline Poor labour supervision and workmanship & 0.50 & 0.50 \\
\hline Little capacity to deal with the complexities of modern projects & 0.33 & 0.67 \\
\hline Contractors, subcontractors, clients and consultants do not work together as a project team & 0.17 & 0.83 \\
\hline Total score on manpower incidents & 5.83 & 2.17 \\
\hline \multicolumn{3}{|l|}{ Materials and equipment category } \\
\hline Lack of technical know-how on quantity surveying of construction material & 0.83 & 0.17 \\
\hline Regular shortages of materials on site & 0.83 & 0.17 \\
\hline Excessive waste of material during the application process (e.g. unnecessarily thick plastering) & 0.67 & 0.33 \\
\hline Non-conformance of material to specification & 0.67 & 0.33 \\
\hline Loss of material on site because of damage or theft & 0.67 & 0.33 \\
\hline Deterioration of materials because of inappropriate storage & 0.50 & 0.50 \\
\hline Regular breakdown of overhead crane and vehicles & 0.50 & 0.50 \\
\hline \multicolumn{3}{|l|}{ Project implementation category } \\
\hline Poor planning techniques and failure to identify critical activities & 1.00 & 0.00 \\
\hline Lack of project coordination among contractors, subcontractors, clients and consultants & 1.00 & 0.00 \\
\hline Unplanned increase in the scope of work from the client & 1.00 & 0.00 \\
\hline Unrealistic construction planned time by clients & 1.00 & 0.00 \\
\hline Failure to commence project on time because of main contractor delays & 0.83 & 0.17 \\
\hline Omissions in the construction plans & 0.83 & 0.17 \\
\hline Time spent waiting for samples, materials approval, site inspection; approval of quality control tests and results & 0.67 & 0.33 \\
\hline Total score on project implementation incidents & 6.33 & 0.67 \\
\hline \multicolumn{3}{|l|}{ Quality category } \\
\hline Architectural drawings lack adequate technical information & 1.00 & 0.00 \\
\hline There is poor supervision of projects by project foremen & 0.83 & 0.17 \\
\hline Failure to deliver projects on time to the satisfaction of the client & 0.67 & 0.33 \\
\hline Poor relationships between small businesses and stakeholders & 0.50 & 0.50 \\
\hline Inability to interpret construction tender plans & 0.33 & 0.67 \\
\hline Inability to produce works of an acceptable standard & 0.33 & 0.67 \\
\hline Poor information flow and coordination between small businesses and stakeholders & 0.17 & 0.83 \\
\hline Total score on quality incidents & 3.83 & 3.17 \\
\hline \multicolumn{3}{|l|}{ Legal and environmental category } \\
\hline Compliance with health and safety regulations is a hindrance to ECs' performance relative to: & 1.00 & 0.00 \\
\hline High costs on medical requirements & 1.00 & 0.00 \\
\hline High costs on personal protection requirements & 1.00 & 0.00 \\
\hline Expensive first aid requirements & 1.00 & 0.00 \\
\hline Cumbersome registration requirements and stringent government and private support systems & 1.00 & 0.00 \\
\hline The grading system in the construction industry & 1.00 & 0.00 \\
\hline Government policies in the construction industry do not promote small-scale construction enterprises & 0.83 & 0.17 \\
\hline Total score on legal and environmental incidents & 6.83 & 0.17 \\
\hline
\end{tabular}


APPENDIX 1 (Continues...): Summary of critical incidents identified.

Financial category

Respondents' perceptions

Agreed score

Disagreed score

\section{Strategic planning category}

Limited work opportunities for emerging contractors, high competition

There is lack of attention to long-term vision

There is lack of clear objective 